\title{
JIKOM
}

Jurnal Ilmiah Komunikasi

Volume 13, No.02, Juli. 2021

\section{Komunikasi antar Budaya Masyarakat Pedalaman Papua Melalui Model Komunikasi di Youtube Expedisi Segaris Episode 9}

\author{
Bagus Budi Santoso ${ }^{1}$, Fatimah ${ }^{2}$, Berliana ${ }^{3}$ \\ 1,2,3 Sekolah Tinggi Ilmu Komunikasi Indonesia Maju \\ Email correspondent: budisantosobagus8@gmail.com
}

\begin{abstract}
Abstrak
Kevin Hendrawan dalam membuat konten di Youtube dengan format atau Jenre Web series yang berjudul Nekat masuk ke Suku pedalaman Papua \#Expedisisegaris Episode 9. Bertujuan untuk memberikan informasi atau edukasi tentang ke aneka ragaman dan adat istiadat yang ada di Papua khususnya Suku Dani. Sifat penelitian ini adalah kualitatif, dengan menggunakan studi kasus. Jenis dan teknik pengumpulan data adalah primer yang diperoleh dari wawancara. Sementara data Skunder diperoleh dari data yang berbentuk buku, web, dan foto. Dengan adanya model Komunikasi antar budaya yaitu faktor budaya, faktor psikologi, faktor sosiologi, faktor lingkungan. Membuat komunikasi antar budaya dengan Suku Dani secara efektif sehingga memperlancar proses komunikasi dan peliputan ekspedisi segaris episode 9 nantinya hasil dari pesan yang disampaikan untuk edukasi masyarakat terhadap budaya suku dani yang di akses lewat akun youtube Kevin Hendrawan.
\end{abstract}

Kata Kunci: komunikasi antar budaya, media youtube, suku dani.

\begin{abstract}
Kevin Hendrawan in creating content on Youtube with the format or Genre Web series entitled Reckless entry into the Papuan inland tribes \#Expeditionary Episode 9. Aiming to provide information or education about the diversity and customs that exist in Papua specifically the Dani tribe. The nature of this research is qualitative, using case studies. The type and technique of data collection are the primary ones obtained from interviews. While secondary data is obtained from data in the form of books, the web, and photographs. With the existence of intercultural communication models namely cultural factors, psychological factors, sociological factors, environmental factors. Making communication between cultures with the Dani tribe effectively so that it expedites the process of communication and coverage of episode 9 expeditionary expedition, the results of messages sent to educate the public about dani tribal culture accessed through the Kevin Hendrawan YouTube account.
\end{abstract}

Keyword: intercultural communication, youtube media, suku dani. 


\section{Pendahuluan}

Indonesia adalah sebuah negara kepulauan dan merupakan salah satu negara yang mempunyai jumlah penduduk terbanyak ke-4 di dunia yakni 238.315.176 jiwa, setelah China sebagai negara terpadat di dunia yakni sebanyak 1.332.451.196 jiwa, dan India sebagai negara terpadat nomor dua di dunia yakni sebanyak 1.065.070.607, lalu disusul oleh Amerika sebanyak 311.05.977. Hal ini didasari data mengenai jumlah penduduk bumi yang dirilis update oleh biro sensus Amerika (IDB) International Data Base pada bulan Agustus 2011. Selain jumlah penduduknya yang banyak, negara Indonesia memiliki posisi yang sangat strategis, yaitu diapit oleh dua benua Asia dan benua Australia serta dua samudera yaitu Samudera Hindia dan Samudera Pasifik. Akibat letak geografisnya yang strategis inilah maka Indonesia banyak disinggahi oleh wisatawan-wisatawan asing baik dengan tujuan berwisata maupun dengan tujuan-tujuan lainnya. ${ }^{1}$

Komunikasi antarbudaya terjadi antar orang-orang yang berbeda bangsa, ras, bahasa, agama, tingkat pendidikan, status sosial atau bahkan jenis kelamin. Komunikasi antarbudaya mengasumsikan bahwa komunikator dan komunikan memiliki latar belakang kebudayaan yang berbeda, sehingga diasumsikan antara komunikator dan komunikasi memiliki perbedaan persepsi terhadap pesan-pesan komunikasi yang disampaikan. ${ }^{2}$

Perkembangan media massa dalam era digital sekarang ini dirasa terhubung dengan kegiatan masyarakat dalam mencari informasi, apalagi kelebihan teknologi yang memudahkannya untuk mengikuti perkembangan zaman. Keterkaitan teknologi dan komunikasi menjadikan media massa (terutama elektronik dan online) menjadi warna baru dalam mengakses segala informasi yang diperlukan oleh masyarakat. Beragam media mulai dari media cetak, elektronik bahkan media online yang di dalamnya terdapat internet. Perkembangan penggunaan media internet sebagai komunikasi menjadi semakin pesat setelah internet mulai dapat diakses melalui telepon seluler dan bahkan kemudian muncul istilah telepon pintar (smartphone). Hadirnya smartphone, fasilitas berkomunikasi pun beraneka macam, mulai dari sms, mms, chatting, email, video live, dan lain-lain yang menyangkut dengan fasilitas sosial media. Penggunaan smartphone yang juga semakin lama semakin bertambah dengan fitur yang disediakan oleh para produsen seluler, salah satu contoh adalah kita dapat menonton video bahkan siaran televisi sekalipun hanya dengan mengetik dan mencarinya dimesin pencarian seperti Google. ${ }^{3}$

Penemuan berbagai macam teknologi informasi memudahkan masyarakat mencari informasi dalam waktu yang cepat. Kecanggihan teknologi tersebut telah memudahkan kita untuk mengakses segala sesuatu yang dapat dilihat melalui internet. Internet itu sendiri terdapat media sosial yang diantaranya adalah YouTube. ${ }^{4}$

Dalam komunikasi antar budaya seperti memuat proses komunikasi nya, kita berusaha memaksimalkan hasil interaksi. Kita berusaha mendapatkan keuntungan yang maksimal dari biaya yang minimum. Dalam komunikasi budaya, orang cenderung akan berinteraksi dengan orang lain yang mereka pikir akan memberikan hasil yang positif, dan bila mendapatkan hasil yang positif maka proses komunikasi tersebut akan terus ditingkatkan, dan ketika dalam proses komunikasi tersebut dirasa mendapat hasil yang negatife maka pelaku komunikasi tersebut mulai menarik diri dan mengurangi proses komunikasi. Hambatan-hambatan yang terjadi mungkin disebabkan karena adanya sikap yang tidak saling pengertian antara satu individu dengan individu lainnya yang berbeda budaya. ${ }^{5}$

Untuk mewujudkan komunikasi yang baik atau efektif dengan latar belakang budaya yang berbeda, tidak sesulit yang kita bayangkan dan tidak semudah anggapan banyak orang. Berkomunikasi dan berinteraksi dalam budaya yang berbeda, banyak hal yang harus diperhatikan dan banyak juga kemungkinan terjadinya kesalahpahaman di dalamnya. Kemajemukan budaya yang ada dalam masyarakat Indonesia, selain memiliki sisi positif, juga memiliki sisi yang negatif. Kemajemukan masyarakat sangat potensial sekali bagi terjadinya konflik sebagai akibat dari perbedaan budaya. Untuk 
menghindari terjadinya konflik diperlukan adanya suatu interaksi antar budaya sehingga tercapai suatu pemahaman mengenai budaya yang berbeda dan pada akhirnya bisa menciptakan kenyamanan dan saling menghargai. ${ }^{6}$

Papua adalah sebuah provinsi terluas Indonesia yang terletak di bagian tengah Pulau Papua. Provinsi Papua dulu mencakup seluruh wilayah Papua bagian barat, namun sejak tahun 2003 dibagi menjadi dua provinsi. Papua memiliki luas $808.105 \mathrm{~km}^{2}$. Suku yang tersebar di pulau Papua dibagi menjadi dua yaitu 1) Suku papua yang berada di Indonesia yang menempati isi sebelah barat pulau Papua/West New Guinea terdiri atas 466 suku bangsa. Diantaranya Suku Dani, Suku Asmat, Suku Bauzi, dan Suku Amungme; dan 2) Suku Papua yang berada di Papua New Guinea yang menempati di sebelah timur yang disebut East New Guinea/Papua Nugini dengan jumlah hampir 800 bahasa. Dari 466 suku bangsa yang menempati wilayah barat Pulau Papua/West New Guinea, Suku Asmat merupakan suku yang paling dikenal dari empat suku yang penulis sebutkan diatas. Tetapi dalam makalah ini penulis akan membahas tentang Suku Dani yang belum cukup dikenal adat dan kebudayaannya. Suku dani adalah salah satu suku yang terdapat di Wamena, Papua yang membentang diantara Pegunungan Tengah Jayawijaya.

Suku Dani merupakan salah satu dari banyaknya suku di tanah Papua yang mendiami wilayah Lembah Baliem, Pegunungan Tengah, dan keseluruhan Kabupaten Jayawijaya serta sebagian kabupaten Puncak Jaya. Sejak ratusan tahun lalu suku Dani dikenal sebagai petani yang terampil dan telah menggunakan alat/perkakas seperti kapak batu, pisau yang dibuat dari tulang binatang, bambu dan juga tombak yang dibuat menggunakan kayu galian yang terkenal sangat kuat dan berat, Pakaian adat Suku Dani untuk pria menggunakan "koteka" (yaitu penutup kemaluan pria). Koteka terbuat dari kunden (labu kuning), sedangkan pakaian adat para wanita menggunakan pakaian wah berasal dari rumput/serat, Bahasa suku Dani termasuk keluarga bahasa Melansia dan bahasa Papua tengah (secara umum), Masyarakat Dani mempunyai seni kerajinan khas, anyaman kantong jaring penutup kepala dan pegikat kapak. Selain itu juga terdapat beberapa peralatan yang terbuat dari bata seperti Moliage, Valuk, Sege, Wim, Kurok, dan Panah sege, Rumah adat suku Dani disebut dengan Honai dan Ebe'ai. Ukurannya tergolong kecil dengan bentuk bundar, berdinding kayu dan beratap jerami.

Penonton juga bisa langsung memberi komentar pada kolom yang telah disediakan, hal ini yang membedakan dengan televisi. Kehadiran YouTube juga menjadi media sosial yang paling diminati masyarakat karena didalamnya terdapat berbagai macam jenis video mulai dari hiburan, tips dan trik, sampai juga berita-berita terupdate. ${ }^{7}$

Youtube merupakan salah satu bentuk media sosial berbasis video yang mulai naik daun sejak 5 tahun yang lalu.. Dilansir dari statistik dalam situsnya sendiri, Youtube memiliki lebih dari satu milyar pengguna yang merupakan hampir sepertiga semua pengguna internet. Hingga Maret 2015, pembuat konten di Youtube sudah mengunggah 10.000 video, karena membuat akun atau channel di Youtube dan meraih pelanggan atau penayangan bisa menghasilkan uang. Lama kelamaan, makin banyak orang membuat akun Youtube yang membuka kesempatan sebagai lapangan pekerjaan. Tiap hari pengguna Youtube bisa menonton ratusan juta jam video dan menghasilkan miliaran kali penayangan. Youtube menjangkau pemirsa rata-rata berusia 18 sampai 34 tahun. Beragam konten video bisa diakses dalam Youtube, mulai dari Musik, Film, Berita dan Informasi, Olahraga, Gaya hidup, Gaming, dan Vlog. Dengan fenomena trend youtube makin memperkaya youtube seperti Atta Halilintar, Ria Ricis yang mana youtuber tersebut membuat konten positif yang disukai oleh penonton sehingga mendapatkan uang dari konten sebut.

Salah satu nya youtuber Indonesia yang sukses, kevin hendrawan ikut mewarnai media youtube, kemunculan kevin hendrawan dalam membuat akun youtube pada tahun 2015 yang mengunggah video berupa vlog, program trivia bertajuk LIMA, program info mengenai lima fakta - fakta unik yang ada di dunia dan webseries video inspirasi, hingga saat ini youtuber Kevin Hendrawan memiliki subscriber 
mencapai 1,69 juta, salah satu konten yang ada dalam youtube kevin hendrawan membahas tentang video sharing inspirasi,VLOGs, salah satu episodenya adalah Nekat Masuk Ke Suku Pedalaman Papua \#Ekpedisi Segaris Eps 9.

Tujuan dari penelitian ini adalah untuk menganalisa Komunikasi Antar Budaya dengan model gudy kunt.

\section{Metode}

Penelitian ini merupakan penelitian deskriptif dengan pendekatan kualitatif. Penelitian deskriptif yaitu penelitian yang bertujuan membuat deskripsi secara sistematis, faktual, dan akurat tentang faktafakta serta sifat tertentu. Pendekatan kualitatif yang dimaksud sebagai prosedur penelitian yang menghasilkan data deskriptif berupa kata-kata tertulis atau lisan dari orang-orang dan perilaku yang dapat diamati. Penelitian deskriptif mencoba mencari deskripsi yang tepat yang cukup dari semua aktivitas, objek, proses, dan manusia. Penelitian deskriptif berkaitan dengan pengumpulan fakta dan data secara valid untuk memberikan gambaran mengenai objek yang diteliti. ${ }^{8}$

Penelitian ini menggunakan metode studi kasus, karena dalam penelitian ini peneliti ingin mengetahui isi dari konten youtuber Kevin Hendrawan yang berjudul Nekat masuk ke pedalaman papua \#Ekspedisisegaris episode 9 tepat nya di suku Dani, dimana isi konten tersebut menggambarkan keanekaragaman, ada istiadat dan kebiasaan dari suku pedalaman yang ada di Papua. Studi kasus adalah memilih target sebagai objek penelitian yang dapat dijelaskan secara terperinci dan komprehensif atau secara medalam. Peneliti ini dimaksudkan untuk memberikan gambaran mengenani suatu proses komunikasi antar budaya yang berada di pedalaman papua, tepatnya pada suku Dani. ${ }^{9}$

Key informan merupakan seseorang yang memang ahli di bidang yang akan diteliti, sementara informan merupakan orang-orang yang relevan dengan bidang yang diteliti, dimana keterangan dari informan diperoleh untuk mengecek kebenaran atau memperkaya informasi dari key informan, pencarian key informan dan informan harus selektif, sehingga upaya penggalian data bisa dilakukan secara maksimal. ${ }^{10}$

Sumber primer adalah sumber data yang secara langsung memberikan data kepada pengumpul data. ${ }^{11}$ Sumber primer ini berupa catatan hasil wawancara yang diperoleh melalui wawancara yang peneliti lakukan. Dalam penelitian ini data dikumpulkan dengan cara wawancara mendalam atau disebut juga dengan indepth interview. Wawancara ini disebut juga dengan wawancara secara mendalam yang bertujuan memperoleh informasi dari semua informan, tetapi susunan kata dan urutannya disesuaikan dengan ciri-ciri setiap informan. Wawancara secara mendalam bersifat fleksibel, susunan pertanyaannya dan susunan kata-kata dalam setiap pertanyaan dapat diubah pada saat wawancara, disesuaikan dengan kebutuhan saat wawancara, termasuk karakteristik sosial-budaya informan yang dihadapi.

Sumber data sekunder merupakan sumber data yang tidak memberikan informasi secara langsung kepada pengumpul data. Sumber data sekunder ini dapat berupa hasil pengolahan lebih lanjut dari data primer yang disajikan dalam bentuk lain atau dari orang lain. Data sekunder diperoleh melalui studi kepustakaan, yaitu mengumpulkan data melalui literatur yang berhubungan dengan penelitian ini, seperti buku-buku, skripsi terdahulu, kamus, website, dan artikel-artikel yang terkait dengan penelitian ini. $^{12}$

Data Kualitatif dapat terdiri dari berbagai macam bentuk, foto, peta, wawancara terbuka, observasi, dokumen dan lainnya. Istilah data merujuk pada material kasar yang dikumpulkan peneliti dari dunia yang sedang diteliti. Menurut Patton terdapat tiga jenis data dalam penelitian kualitatif. ${ }^{13}$

Observasi dilakukan untuk mendekatkan peneliti ke orang-orang yang ditelitinya dan ke situasi atau lingkungan mereka yang sebenarnya. Dan peneliti dapat masuk ke lingkungan yang ditelitinya atau 
yang dikenal dengan observasi partisipatif. Pada observasi ini, peneliti mengamati peristiwa, kejadian, pose, dan sejenisnya disertai dengan daftar yang perlu diobservasi. ${ }^{14}$

Wawancara adalah hasil bersama seorang peneliti dan satu atau lebih anggota. Anggota adalah peserta aktif yang wawasan, perasaan, dan kerjasamanya menjadi bagian penting dari proses pembahasan yang mengungkapkan makna subjektif. Wawancara melibatkan rasa berbagi pengalaman maupun latar belakang untuk mendorong keterbukaan dari informan.

Metode dokumentasi adalah metode pengumpulan data yang datanya diperoleh dari buku, internet, atau dokumen lain yang menunjang penelitian yang dilakukan. Dokumen merupakan catatan mengenai peristiwa yang sudah berlalu. Peneliti mengumpulkan dokumen yang dapat berupa tulisan, gambar, atau karya-karya monumental dari seseorang.

Mereduksi berarti merangkum, memilih hal-hal pokok dan penting kemudian dicari tema dan polanya. Pada tahap ini peneliti memilah informasi mana yang relevan dan mana yang tidak relevan dengan penelitian. Setelah direduksi data akan mengerucut, semakin sedikit dan mengarah ke inti permasalahan sehingga mampu memberikan gambaran yang lebih jelas mengenai objek penelitian. Setelah dilakukan reduksi data, langkah selanjutnya adalah menyajikan data. Data disajikan dalam bentuk tabel dan uraian penjelasan yang bersifat deskriptif. Tahap akhir pengolahan data adalah penarikan kesimpulan. Setelah semua data tersaji permasalahan yang menjadi objek penelitian dapat dipahami dan kemudian ditarik kesimpulan yang merupakan hasil dari penelitian ini.

\section{Hasil dan Pembahasan}

\section{Analisis Model Komunikasi antar Budaya. Masyarakat Pedalaman Papua melalui Model Komunikasi di Youtube Expedisi Segaris Episode 9}

Web series merupakan media audio-visual yang memaparkan pesan yang ditangkap melalui indra penglihatan serta indra pendengaran. Dalam proses komunikasi web series merupakan salah satu alat penyampaian berbagai jenis pesan. Web series juga sering disebut sebagai video atau movie. Web Series dalam penelitian ini adalah sebuah karya dari Kevin Hendrawan yang berjudul "Nekat Masuk Ke Pedalaman Papua \#EkspedisiSegaris Episode 9".

Web Series merupakan sebuah konsep acara berseri yang dirilis dalam medium internet, biasanya Youtube menjadi platform utama bagi para produser web series. Format web series ini sebenarnya mirip dengan acara yang ditayangkan di televisi, tetapi ada perbedaan dalam platform dan konten yang ditayangkan, dimana dalam web series ini Kevin Hendrawan mengexplore bagaimana rasanya tinggal di suku pedalaman di Indonesia. Mengikuti berbagai tradisi adat istiadat hingga perang suku, banyak sekali perbedaan yang ada di Indonesia, tapi beda itu indah dan justru makin membuat Kevin Hendrawan merasa bersyukur bisa mengenal berbagai perbedaan yang ada di Indonesia.

Tahapan yang dilakukan oleh Kevin Hendrawan saat membuat web series yang berjudul "Nekat Masuk Ke Pedalaman Papua \#EkspedisiSegaris Episode 9 dimulai dari mencari informasi tentang keberadaan dan keragaman budayanya, dalam tahapan pra produksi (tahap perencanaan) Kevin Hendrawan dibantu oleh PT.Origami Picture dan PT. FiberCreme dalam membuat alur cerita dan dalam mengembangkan cerita supaya nantinya pesan yang akan disampaikan oleh Kevin Hendrawan pada konten web series tersebut tersampaikan. Pada Tahapan Produksi Kevin Hendrawan hanya dibantu oleh tim dari PT. Fiber Crème saja, karena tim dari PT.Origami Picture memfokuskan pembuatan konsep dan konten lainnya untuk kebutuhan web series kevin selanjutnya. Pada tahapan pasca produksi (editing) Kevin Hendrawan dibantu lagi oleh PT.Origami Picture dan PT.Fiber Crème dalam proses editing sampai nantainya di posting ke akun youtube Kevin Hendrawan.

Dalam konten web series yang berjudul "Nekat Masuk Ke Pedalaman Papua \#EkspedisiSegaris Episode 9" Kevin Hendrawan dibantu oleh PT. Origami Picture dan PT. Fiber Crème dalam membuat alur cerita dalam pembuatan web seriesnya. seperti yang diutarakan oleh sutradara. 
Dalam membuat konten web series yang berjudul_"Nekat Masuk Ke Pedalaman Papua \#EkspedisiSegaris Episode 9" Kevin Hendrawan ingin mengexplore dan mengetahui adat istiadat serta keragaman budaya yang ada di papua khususnya suku dani, seperti yang diutarakan oleh sutradara.

Dalam Proses pembuatan web series yang berjudul "Nekat Masuk Ke Pedalaman Papua \#EkspedisiSegaris Episode 9" kami PT Fiber crème mengaplikasikan model komunikasi antar budaya gudy kunt. Dalam proses produksi kami PT Fiber Crème dibantu oleh agen biro perjalanan Papua yang membantu kami baik akomodasi sampai bisa masuk ke dalam Suku Dani. Pada saat produksi web series 9 ini kami mengalami kesulitan produksi, Kevin Hendrawan mengalami kesulitan dan berkomunikasi, lantaran Kevin tidak menguasai bahasa suku Dani dan membuat Kevin Hendrawan harus beradaptasi dengan bahasa tersebut.

\section{Faktor Budaya, Faktor Sosiobudaya, Faktor Psikobudaya dan Faktor Lingkungan}

Pengaruh sosio kultur akan tampak pada proses penataan sosial yang berkembang berdasarkan interaksi dengan orang lain ketika pola-pola perilaku menjadi konsisten dengan berjalannya waktu. Ada empat faktor utama dalam sosio budaya, antara lain keanggotaan dalam kelompok sosial, konsep diri, expetasi peran, dan definisi mengenai hubungan antar pribadi. Dalam proses komunikasi antar budaya dengan suku dani Kevin Hendrawan sangat terkesan, dengan keanekaragaman yang dimiliki suku dani bahasan membuat Indonesia sangat menarik untuk di explore dan menjadi pengetahuan baru untuk Kevin Hendrawan pribadi dan bagi masyarakat lainnya.

Toleransi budaya suku dani membuat keberadaan suku dani menjadi sangat menarik untuk di explore, Kevin Hendrawan tidak menyia-nyiakan keragaman budaya dan adat istiadat disana dengan cara mengexplore suku dani lewat alur cerita yang menarik, seperti yang diutarakan oleh kru kreatif dan sutradara. Keanekaragaman adat istiadat dari suku dani membuat Kevin Hendrawan tertarik membuat web series dengan judul "Nekat Masuk Ke Pedalaman Papua \#EkspedisiSegaris Episode 9" untuk memberikan edukasi terhadap masyarakat tentang adat istiadatnya dan salah satu ragam budaya yang ada di Indonesia, serta dikemas dalam bentuk audio visual lewat alur cerita yang menarik.

Dimensi psiko kultur mencakup proses penataan pribadi. Penataan pribadi adalah proses yang memberi stabilitas pada proses psikologis. Faktor-faktor dalam psikobudaya adalah stereotip dan sikap terhadap kelompok lain. Kedua faktor tersebut menciptakan pengharapan mengenai cara orang lain berperilaku, dan pada akhirnya akan mempengaruhi cara kita menafsirkan stimulus yang datang dan prediksi kita tentang perilaku orang lain.

Faktor dalam psikobudaya sikap terhadap kelompok lain, pembuatan konten youtube Kevin Hendrawan untuk mengetahui budaya mereka serta menghormati budaya Suku Dani hal ini sesuai dengan wawancara sutradara. Lingkungan akan mempengaruhi kita dalam melakukan penyandian dan penyandian balik suatu pesan. Lingkungan mencakup iklim, lokasi geografis, lingkungan fisik, dan persepsi kita atas suatu lingkungan. Sesuai dengan informasi sutradara dan kru kreatif. Komunikasi antar budaya adalah komunikasi antar pribadi yang dilakukan oleh komunikator dan komunikan yang berbeda budaya, dalam satu bangsa sekalipun. Komunikasi dan budaya ibarat dua sisi mata uang yang tidak terpisahkan dan saling mempengaruhi satu sama lain. Budaya tidak hanya menentukan siapa bicara dengan siapa, tentang apa dan bagaimana komunikasi berlangsung, tetapi budaya juga turut menentukan cara orang menyandi pesan, makna yang dimiliki untuk pesan dan kondisinya untuk mengirim, memerintahkan, dan menafsirkan pesan.

Berdasarkan penelitian wawancara diatas, dapat diperoleh bahwa komunikasi antar budaya sangat berperan penting dalam penelitian ini yang berjudul Nekat Masuk Ke Suku Pedalaman Papua \#Ekspedisisegaris Episode 9. Komunikasi antar budaya yang dilakukan Kevin Hendrawan dan suku Dani sangat efektif dikarenakan team kreatif PT Fiber Crème sangat menjaga dan menghormati Adat 
istiadat Suku Dani dalam web series yang berjudul "Nekat Masuk Ke Pedalaman Papua \#EkspedisiSegaris Episode 9" dapat terlaksana dengan lancar.

Model komunikasi antar budaya yang digunakan untuk memperlancar Komunikasi Antar Budaya dengan Suku Dani yaitu: awal nya Kevin Hendrawan mengalami kesulitan dalam berkomunikasi, namun berkat bekerja sama dengan agent yang menangani biro perjalanan di Papua sehingga saya sebagai sutradara mampu mengarahkan kevin hendrawan sedikit demi sedikit agar membaur dengan suku dani tersebut,sehingga Kevin Hendrawan sedikit demi sedikit memahami dan mengerti bahasa dari suku dani" biro perjalanan yang kami pilih ini sangat mengenal budaya bahasa dan adat istiadat Suku Dani. Agen biro perjalanan sengaja kita pilih orang Papua yang mengenali Suku Dani sehingga memudahkan kita berkomunika si dengan Suku Dani. Mayoritas Suku Dani beragama Kristen protestan dan Agama Islam sunni, kalo minoritas Suku Dani beragama Katolik Animisme, Animatis, Dinamisme dan Totem. Untuk menghindari kesalah pahaman, Tradisi potong jari atau di sebut juga Tradisi iki palek. Tradisi potong jari yang mereka lakukan untuk menunjukan berapa banyak keluarga mereka yang telah meninggal, menurut Suku Dani rasa sakit dari memotong jari di anggap mewakili hati dan jiwa yang tercabik-cabik karena kehilangan anggota keluarga.

Dalam proses komunikasi antar budaya terdapat beberapa perilaku komunikasi individu yang digunakan untuk menyatakan identitas sosial. Perilaku itu dinyatakan melalui tindakan berbahasa, baik secara verbal dan non-verbal. Dari perilaku berbahasa dapat diketahui identitas diri maupun sosial, misalnya asal-usul Suku bangsa, agama, atau pun tingkat Pendidikan seseorang. Inti konsep integrase social adalah menerima kesatuan dan persatuan antar pribadi atau antar kelompok dengan tetap mengakui perbedaan setiap unsur-unsurnya. Salah satu tujuan komunikasi adalah memberikan makna yang sama atas pesan yang dibagi antara komunikator dan komunikan, integrasi social merupakan tujuan utama komunikasi. Prinsip utama dalam proses pertukaran pesan komunikasi antar budaya adalah memperlakukan pihak sebagaimana kebudayaan orang tersebut memperlakukan orang tersebut. Komunikasi antar pribadi ataupun anatr budaya akan menambah pengetahuan Bersama karena pihak yang berkomunikasi saling mempelajari kebudayaan masing-masing. Komunikasi adakalanya ditujukan untuk melepaskan diri atau mencari jalan keluar atas masalah yang sedang dihadapi seseorang.

Interaksi yang terjadi antara Kevin Hendrawan dan Masyarakat Suku Dani banyak memberi pengetahuan baru untuk kevin, mengingat perbedaan agama yang ada pada Suku Dani tidak menghargai setiap perbedaan serta masih memegang teguh pada kebudayaan nenek moyang mereka. Tentu nya kevin komunikasi dan berinteraksi sama beberapa masyarakat Suku Dani, mereka sangat terbuka dan antusias sekali ingin ngobrol atau sekedar bercanda sama kevin, kalau saya menggambarkan pada saat itu persepsi mereka terhadap orang Asing yang datang sangat Welcome sekali. Tujuan komunikasi antar budaya adalah mengurangi tingkat ketidakpastian tentang orang lain. Pertemuan antara dua orang dapat menimbulkan permasalahan mengenai relasi keduanya, dan muncullah beberapa pertanyaan tentang perasaan, sikap seseorang, dan hal-hal yang akan jika berkomunikasi dengannya, dan pertanyaan lainnya.

Diperoleh Kebingungan yang dituangkan dalam pertanyaan tersebut akan mendorong seseorang untuk berkomunikasi sehingga permasalahan relasi terjawab. Selanjutnya, setelah berkomunikasi, seseorang akan mengambil keputusan untuk meneruskan atau menghentikan komunikasi tersebut.

Menurut teori yang menjelaskan bahwa dengan penggunaan sistem sandi yang sama, pengakuan atas perbedaan dalam kepercayaan dan perilaku, serta pemupukan sikap toleran terhadap kepercayaan dan perilaku orang lain, akan membantu terciptanya komunikasi yang efektif. ${ }^{15}$

Komunikasi Antar budaya yang Kevin Hendrawan pakai untuk berinteraksi kepada Suku Dani meliputi empat faktor yaitu: faktor budaya, faktor sosiobudaya, faktor psikobudaya, dan faktor 


\section{JIKOM}

Jurnal Ilmiah Komunikasi

Volume 13, No.02, Juli. 2021

lingkungan yang menjadikan modal Kevin Hendrawan dalam mencari tahu keanekaragaman yang ada di Suku Dani.

\section{Kesimpulan}

Berdasarkan dari hasil penelitian, dapat diperoleh bahwa Komunikasi Antar Budaya menurut Gudy Kunt sangat berperan penting untuk Kevin Hendrawan berinteraksi kepada Suku Dani guna mendapatkan informasi tentang keanekaragaman budaya dan adat istiadat lewat empat faktor konseptual yang mempengaruhi komunikasi penyandian pesan dan penyandian balik pesan, meliputi: Faktor budaya, faktor sosiobudaya, Faktor psikobudaya, Faktor lingkungan.

\section{References}

1. S BU. Dinamika Penggunaan Lahan di wilayah Perkotaan (Studi di Kota Bandar Lampung). Semin HasilHasil Penelit dan Pengabdi Kpd Masyarakat- Dies Natalis FISIP Unila Tahun 2012. Published online 2012.

2. Mulyana D, Rakhmat J. Komunikasi antarbudaya. In: Penantar Komunikasi Antarbudaya ; 2010.

3. Setiadi A. Pemanfaatan media sosial untuk efektifitas komunikasi. J Hum. Published online 2016.

4. Simarmat. Pengenalan Teknologi Komputer dan Informasi. In: Yogyakarta. Andi Offset; 2006.

5. Utami LSS. Teori-Teori Adaptasi Antar Budaya. J Komun. Published online 2015.

6. Ridwan. Problematika Keragaman Kebudayaan Dan Alternatif Pemecahan. J Madaniyah. Published online 2015.

7. Ali Akbar. Efektifitas Youtube Sebagai Media Penyebaran Informasi Efektifitas Youtube Sebagai Media Penyebaran Informasi(Studi Pada Serambi On Tv). Fakultas Dakwah Dan Komunikasiuniversitas Islam Negeri Ar-Ranirybanda Aceh. 2018.

8. Basuki S. Metode Penelitian. Jakarta. Penaku; 2010.

9. Bungin B. Metodologi Penelitian Kualitatif.; 2011.

10. Dr. Uhar Suharsaputra. M.Pd. Metode Penelitian Kuantitatif, Kualitatif Dan Tundakan; 2014.

11. Sugiyono. Metode Penelitian. Penelitian. Published online 2017.

12. Adi R. Metodologi penelitian sosial dan hukum. In: Metodologi Penelitian; 2004.

13. Ibrahim D. Metodologi Penelitian Kualitatif. In: Journal Equilibrium. ; 2009.

14. Moleong LJ. Metodologi Penelitian Kualitatif, Cet; 2018.

15. Morissan. Teori Komunikasi ndividu Hingga Massa. Teor Komun. Published online 2013. 